\section{Abscisic Acid Applications Decrease Stomatal Conductance and Delay Wilting in Drought-stressed Chrysanthemums}

\author{
Nicole L. Waterland ${ }^{1}$, John J. Finer, and Michelle L. Jones ${ }^{2}$
}

ADDITIONAL INDEX WORDs. ABA, antitranspirants, Chrysanthemum $\times$ morifolium, floriculture, shelf life extension

SUMMARY. Drought stress during shipping and retailing reduces the postproduction quality and marketability of potted plants. Plants respond to drought stress by closing their stomata and reducing transpirational water loss. This stress response is mediated by the plant hormone abscisic acid (ABA). Exogenous applications of $s$-abscisic acid ( $\mathrm{s}-\mathrm{ABA}$ ), the biologically active form of the hormone, can enhance drought tolerance and extend shelf life in a variety of bedding plants. However, little is known about the effectiveness of s-ABA at enhancing drought tolerance in perennial crops like chrysanthemum (Chrysanthemum $\times$ morifolium). 'Festive Ursula' chrysanthemum plants were drenched $\left(0,125,250\right.$, or $\left.500 \mathrm{mg} \cdot \mathrm{L}^{-1}\right)$ or sprayed $\left(0,500\right.$, or $\left.1000 \mathrm{mg} \cdot \mathrm{L}^{-1}\right)$ with $\mathrm{s}$-ABA. All applications containing $\mathrm{s}$-ABA effectively delayed wilting by reducing stomatal conductance $\left(g_{s}\right)$. Shelf life was extended from 1.2 to 4.0 days depending on the concentration of s-ABA. Spray applications of $500 \mathrm{mg} \cdot \mathrm{L}^{-1} \mathrm{~s}-\mathrm{ABA}$ to six additional chrysanthemum cultivars increased shelf life from $\mathbf{1 . 6}$ to $\mathbf{3 . 8}$ days following drought stress. s-ABA treatment also allowed severely drought-stressed chrysanthemums to recover and remain marketable after rewatering. Growers can treat chrysanthemums with s-ABA to reduce water use during shipping and to delay wilting if plants are not adequately watered during retailing.

$\mathrm{P}$ lants may be exposed to high temperatures and irregular or infrequent irrigation during shipping and retailing. These poor postproduction environments cause rapid substrate drying, plant wilting, and accelerated senescence. Drought stress is a major cause of postproduction decline in greenhouse crops, and plants quickly become unsalable (Armitage, 1993; Barrett and Campbell, 2006; van Iersel et al., 2009). The ABA helps

Department of Horticulture and Crop Science, The Ohio Agricultural Research and Development Center, The Ohio State University, Wooster, OH 44691

The information in this publication is for educational purposes only. Mention of a trademark, proprietary product, or vendor does not constitute a guarantee or warranty of the product, nor does it imply approval or disapproval to the exclusion of other products or vendors that may also be suitable.

This research was funded by the Ohio State University D.C. Kiplinger Floriculture Endowment, the Valent BioSciences Corporation, and the Gladys Wittmeyer Knox-Gene Wittmeyer Scholarship. Salaries and research support were provided in part by State and Federal funds appropriated to the Ohio Agricultural Research and Development Center, The Ohio State University.

Journal Article Number HCS 10-05.

We thank Green Circle Growers for their donation of plant material and Valent BioSciences for donation of chemicals.

${ }^{1}$ Current address: Division of Plant and Soil Sciences, West Virginia University, Morgantown, WV 26506.

${ }^{2}$ Corresponding author. E-mail: jones.1968@osu.edu. plants survive drought stress by closing stomata to reduce transpirational water loss and prevent wilting (Malladi and Burns, 2007).

Antitranspirants can be used by producers to prevent wilting and extend the postproduction shelf life and marketability of floriculture crops (Goreta et al., 2007; Martin and Link, 1973). These products enhance drought tolerance by providing a physical barrier to water loss or by inducing stomatal closure. Physical antitranspirants contain resins, polymers, or waxes that coat the leaves and block the stomata. Physiological antitranspirants reduce transpiration rates by inducing the plants to close their stomata. These products may contain ABA or other chemicals that cause the plant to produce ABA. Prolonged stomatal closure and reduced transpiration can lead to heat stress under high temperatures, and antitranspirants may also cause phytotoxicity (Blanchard et al., 2007;
Kim and van Iersel, 2008; Waterland et al., 2010a, 2010b). Additional research is therefore needed to evaluate antitranspirants and determine how they can be used to enhance the postproduction quality of specific greenhouse and nursery crops.

Comparative research has shown that antitranspirants containing $\mathrm{ABA}$ are more effective than physical antitranspirants at reducing water loss and delaying drought-induced wilting (Goreta et al., 2007). A new commercial product containing s-ABA, the biologically active form of $\mathrm{ABA}$, ConTego (Valent BioSciences, Libertyville, IL), delays wilting in a variety of bedding plants under severe drought stress (Blanchard et al., 2007; Kim and van Iersel, 2008; Waterland et al., 2010a, 2010b). Little is known about the effectiveness or phytotoxicity of s-ABA on potted crops like chrysanthemum. Chrysanthemums are an important fall crop that accounts for about $20 \%$ of the total potted perennial market in the United States (U.S. Department of Agriculture, 2009). Enhancing their postproduction drought tolerance would result in considerable savings to retailers and producers.

The goal of this research was to determine if s-ABA could be used to enhance the drought tolerance of garden chrysanthemums without any phytotoxicity. Our objectives were 1) to determine if exogenous application of s-ABA delays wilting in finished chrysanthemums exposed to drought stress and 2) to identify any symptoms of phytotoxicity that would negatively affect the marketability of treated chrysanthemums.

\section{Materials and methods Plant materials and experimental treatments}

Expт. 1. 'Festive Ursula' chrysanthemums in 6-inch-diameter pots were obtained from Green Circle Growers (Oberlin, $\mathrm{OH}$ ), and Expt. 1 was conducted in Wooster, $\mathrm{OH}$, from 28 Sept. to 9 Oct. 2007. Average greenhouse temperatures were $26 / 21 \pm 2 / 3^{\circ} \mathrm{C}$

\begin{tabular}{llll}
\hline $\begin{array}{l}\text { Units } \\
\begin{array}{l}\text { To convert U.S. to SI, } \\
\text { multiply by }\end{array}\end{array}$ & U.S. unit & SI unit & $\begin{array}{l}\text { To convert SI to U.S., } \\
\text { multiply by }\end{array}$ \\
\hline 29.5735 & $\mathrm{fl} \mathrm{oz}$ & $\mathrm{mL}$ & 0.0338 \\
2.54 & inch $(\mathrm{es})$ & $\mathrm{cm}$ & 0.3937 \\
1 & $\mathrm{ppm}$ & $\mathrm{mg} \cdot \mathrm{L}^{-1}$ & 1 \\
$\left({ }^{\circ} \mathrm{F}-32\right) \div 1.8$ & ${ }^{\circ} \mathrm{F}$ & ${ }^{\circ} \mathrm{C}$ & $\left(1.8 \times{ }^{\circ} \mathrm{C}\right)+32$
\end{tabular}


day/night with daytime (0700$1800 \mathrm{HR}$ ) average relative humidity of $59.7 \% \pm 7.3 \%$. Plants were irrigated daily with $15 \mathrm{~N}-2.2 \mathrm{P}-12.5 \mathrm{~K}$ fertilizer (Peters Excel ${ }^{\circledR}$ Cal-Mag 15-5-15; Scotts-Sierra Horticulture Products, Marysville, $\mathrm{OH}$ ) at $200 \mathrm{mg} \cdot \mathrm{L}^{-1} \mathrm{ni}^{-}$ trogen $(\mathrm{N})$ and were grown under natural irradiance with supplemental lighting provided by high-pressure sodium and metal halide lamps (GLX/GLS e-systems GROW lights; PARsource, Petaluma, CA). An average photosynthetic photon flux $(P P F)$ of $176 \mu \mathrm{mol} \cdot \mathrm{m}^{-2} \cdot \mathrm{s}^{-1}$ (maximum PPF of $600 \mu \mathrm{mol} \cdot \mathrm{m}^{-2} \cdot \mathrm{s}^{-1}$ ) was provided from 0700 to $1800 \mathrm{HR}$ daily, with a mean daily light integral (DLI) of $7.6 \mathrm{~mol} \cdot \mathrm{m}^{-2} \cdot \mathrm{d}^{-1}$.

Chrysanthemums were treated with either a spray or drench application of s-ABA (ConTego) at the half open flower stage [stage 3 (Syngenta Flowers Inc., 2010)]. All chrysanthemums were irrigated $12 \mathrm{~h}$ before the application of s-ABA. s-ABA was applied as a drench at $0,125,250$, or $500 \mathrm{mg} \cdot \mathrm{L}^{-1}(60 \mathrm{~mL}$ per container) or as a spray at 0,500 , or $1000 \mathrm{mg} \cdot \mathrm{L}^{-1}$ $(\approx 22.3 \mathrm{~mL}$ per plant, until the leaves were wet) with the addition of $0.05 \%$ surfactant (CapSil; Aquatrols, Cherry Hill, NJ). Spray applications were performed with a backpack sprayer (Regulator Bak-Pak; H.D. Hudson, Chicago, IL). Half of the plants from each ABA treatment had water withheld (drought-stressed) and the other half were irrigated daily. After $6 \mathrm{~d}$, the drought-stressed plants were rewatered to evaluate plant recovery. The initial rewatering was with clear reverse osmosis water and all subsequent irrigations were with $100 \mathrm{mg} \cdot \mathrm{L}^{-1} \mathrm{~N}$. Rewatered plants were then irrigated for $3 \mathrm{~d}$.

Stomatal conductance readings were taken using a steady-state porometer (LI-1600; LI-COR, Lincoln, $\mathrm{NE}$ ). Three basal leaves per plant were tagged and the same leaves were used for $g_{S}$ measurements at each time point. Stomatal conductance was measured $1 \mathrm{~d}$ before s-ABA treatment $(-1 \mathrm{~d})$ and 1,3 , and $9 \mathrm{~d}$ after treatment (for drought-stressed chrysanthemums, $9 \mathrm{~d}$ was equivalent to $6 \mathrm{~d}$ of withholding water followed by $3 \mathrm{~d}$ of rewatering). Readings were taken at the same time each day, and data are the average of three replications, with three leaves measured per replication $(\mathrm{n}=3)$.

Ехрт. 2. Finished 8-inch-diameter pots of chrysanthemum cultivars Brandi,

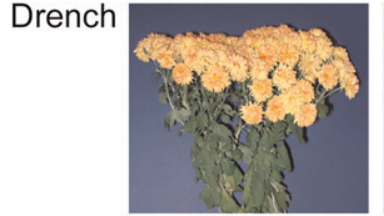

$0 \mathrm{mg} \cdot \mathrm{L}^{-1}$

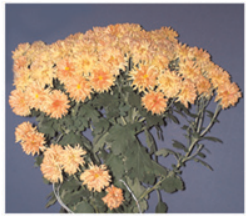

$125 \mathrm{mg} \cdot \mathrm{L}^{-1}$

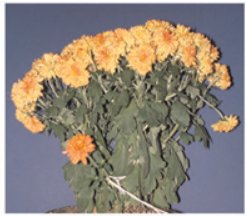

$250 \mathrm{mg} \cdot \mathrm{L}^{-1}$

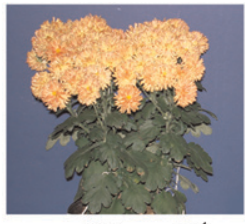

$500 \mathrm{mg} \cdot \mathrm{L}^{-1}$

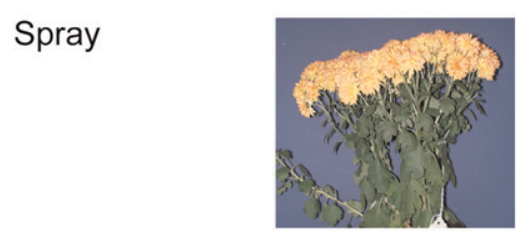

$0 \mathrm{mg} \cdot \mathrm{L}^{-1}$

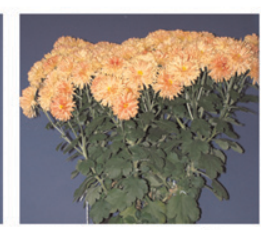

$500 \mathrm{mg} \cdot \mathrm{L}^{-1}$

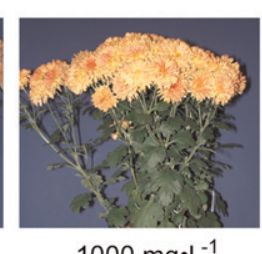

$1000 \mathrm{mg} \cdot \mathrm{L}^{-1}$
Fig. 1. Visual observation of drought-stressed 'Festive Ursula' chrysanthemum after treatment with $s$-abscisic acid (s-ABA) as a drench at $0,125,250$, or 500 $\mathrm{mg} \cdot \mathrm{L}^{-1}(\mathrm{ppm})$ or as a spray at 0,500 , or $1000 \mathrm{mg} \cdot \mathrm{L}^{-1}$. Images of plants are after $3 \mathrm{~d}$ of drought stress and s-ABA treatment; $1 \mathrm{mg} \cdot \mathrm{L}^{-1}=1 \mathrm{ppm}$.

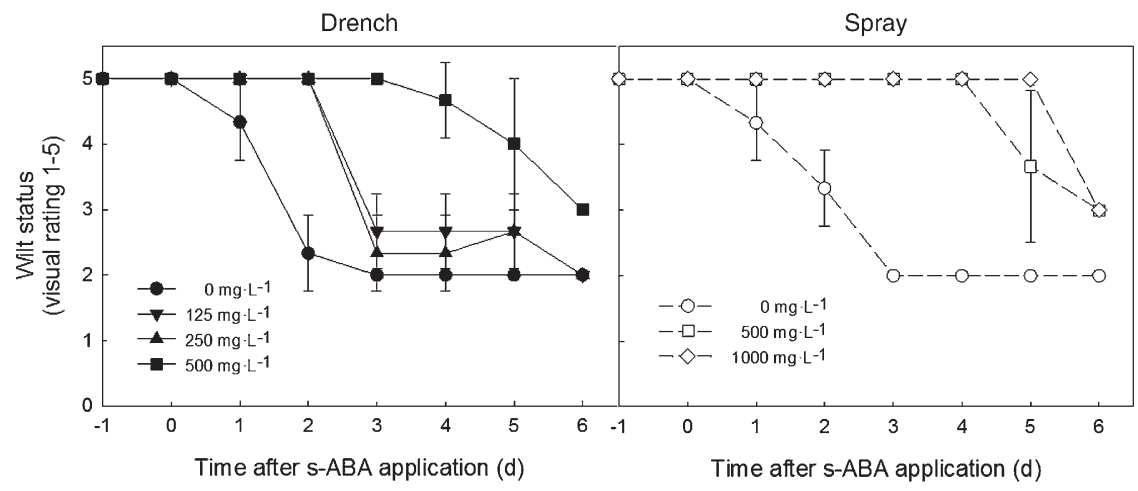

Fig. 2. Wilt status ratings of drought-stressed 'Festive Ursula' chrysanthemum treated with $\mathrm{s}$-abscisic acid (s-ABA) as a drench at $0,125,250$, or $500 \mathrm{mg} \cdot \mathrm{L}^{-1}$ or as a spray at 0,500 , or $1000 \mathrm{mg} \cdot \mathrm{L}^{-1}$. Chrysanthemums were drought-stressed for 6 $\mathrm{d}$ after s-ABA application. Wilt status ratings were from 5 to 1 , where 5 = completely turgid, 4 = soft to touch and starting to wilt, 3 = wilted, $2=$ severely wilted, and $\mathrm{l}=$ wilted to the point that leaves were dry and desiccated. Visual ratings were taken daily. Day -1 is $1 \mathrm{~d}$ before $s-A B A$ application. Values are the means $\pm S D$ of three replications $(\mathrm{n}=3) ; 1 \mathrm{mg} \cdot \mathrm{L}^{-1}=1 \mathrm{ppm}$.

Table 1. Days until the appearance of visual symptoms of wilting and shelf life extension of drought-stressed 'Festive Ursula' chrysanthemum treated with s-abscisic acid (s-ABA).

\begin{tabular}{lccc}
\hline & $\begin{array}{c}\text { Application method } \\
\text { and s-ABA concn }\left(\mathbf{m g} \cdot \mathrm{L}^{-1}\right)^{\mathbf{z}}\end{array}$ & $\begin{array}{c}\text { Time until visually } \\
\text { wilted }(\mathbf{d})^{\mathbf{y}}\end{array}$ & $\begin{array}{c}\text { Shelf life } \\
\text { extension }(\mathbf{d})^{\mathbf{x}}\end{array}$ \\
\hline Drench & 0 & $1.7 \mathrm{c}^{\mathrm{w}}$ & \\
& 125 & $2.9 \mathrm{~b}$ & 1.2 \\
& 550 & $2.9 \mathrm{~b}$ & 1.2 \\
Spray & 500 & $5.7 \mathrm{a}$ & 4.0 \\
& 500 & $2.2 \mathrm{~b}$ & 3.1 \\
& 1,000 & $5.3 \mathrm{a}$ & 3.8 \\
\hline
\end{tabular}

${ }^{\mathrm{z}} \mathrm{l} \mathrm{mg} \cdot \mathrm{L}^{-1}=1 \mathrm{ppm}$.

y Values are the average number of days from Day 0 that it took for each plant to show visible symptoms of wilting, which was a rating of 3 (wilted) on the wilt status rating scale of 5 to 1 , where $5=$ completely turgid, $4=$ soft to the touch and starting to wilt, 3 = wilted, 2 = severely wilted, and $1=$ wilted to the point that leaves were dry and desiccated. Values are means of three replications $(n=3)$.

${ }^{x}$ Shelf life extension refers to the number of additional days from the time the control plants wilted until the s-ABAtreated plants wilted.

${ }^{\text {w } M e a n s ~ w i t h i n ~ t h e ~ s a m e ~ t r e a t m e n t ~(s p r a y ~ o r ~ d r e n c h) ~ f o l l o w e d ~ b y ~ t h e ~ s a m e ~ l e t t e r ~ a r e ~ n o t ~ s i g n i f i c a n t l y ~ d i f f e r e n t ~ a t ~} P \leq$ 0.05 as determined by the least significant difference test. 
Colina Red, Flashy Gretchen, Golden Cheryl, Regina, and Wilma were obtained from Green Valley Growers (Ashland, OH). Plants were grown under normal greenhouse conditions, as described earlier, in Wooster, $\mathrm{OH}$, from 21 Sept. to 15 Oct. 2009. Average greenhouse temperatures were $23 / 16 \pm 2 / 2{ }^{\circ} \mathrm{C}$ day/night with daytime (0600-1800 HR) average relative humidity of $49.8 \% \pm 11.6 \%$. The average $P P F$ was $259 \mu \mathrm{mol} \cdot \mathrm{m}^{-2} \cdot \mathrm{s}^{-1}$ (maximum $P P F$ of $\left.924 \mu \mathrm{mol} \cdot \mathrm{m}^{-2} \cdot \mathrm{s}^{-1}\right)$ from 0600 to 1800 HR daily (DLI of 12.9 $\left.\mathrm{mol} \cdot \mathrm{m}^{-2} \cdot \mathrm{d}^{-1}\right)$. Before $\mathrm{s}$-ABA application, plants were irrigated daily at the same time each day with $100 \mathrm{mg} \cdot \mathrm{L}^{-1} \mathrm{~N}$ as described previously.

All plants were irrigated $12 \mathrm{~h}$ before an application of s-ABA. Spray applications of s-ABA were applied at 0 or $500 \mathrm{mg} \cdot \mathrm{L}^{-1}(\approx 33.3 \mathrm{~mL}$ per plant, until leaves were wet) with $0.05 \%$ surfactant (CapSil). Chrysanthemums were treated with s-ABA when they were at the marketable stage of a few open flowers per plant [stage 2 (Syngenta Flowers Inc., 2010)]. The application rate of $500 \mathrm{mg} \cdot \mathrm{L}^{-1} \mathrm{~s}-\mathrm{ABA}$ was selected based on the results from Expt. 1. Half of the chrysanthemums were irrigated daily and the other half were severely drought-stressed by completely withholding water until the s-ABA-treated plants wilted. Irrigated plants were watered daily with $100 \mathrm{mg} \cdot \mathrm{L}^{-1} \mathrm{~N}$. After all of the s-ABAtreated plants within a cultivar reached a wilt status rating of 3 , the plants were rewatered. Rewatering occurred for $3 \mathrm{~d}$ as stated previously. Data are the average of four replications with one plant per replication $(n=4)$.

EVAluations of WILT STATUS. Visual observations were taken daily in Expts. 1 and 2. All visual observations were based on whole plant wilt status. Wilt status ratings were from 5 to 1 , where $5=$ completely turgid, $4=$ soft to the touch and starting to wilt, 3 = wilted, 2 = severely wilted, and $1=$ wilted to the point that leaves were dry and desiccated. Plants with a rating of 3 or less were considered to be unmarketable.

Statistical analysis. Experiments were conducted in a completely randomized block design, which was blocked by replication and watering treatment (irrigated daily vs. droughtstressed). Values obtained from $g_{s}$ and visual observations were analyzed by Proc GLM (generalized linear model) with least significant difference means separation test at $P \leq 0.05$ using SAS (version 9.1.3; SAS Institute, Cary, NC).

\section{Results and discussion}

Expt. 1. Determining efFecTIVE S-ABA CONCENTRATION AND APPLICATION METHOD. All concentrations of s-ABA and both application methods were effective at delaying wilting in drought-stressed chrysanthemums 'Festive Ursula', with no apparent phytotoxicity (Figs. 1 and 2). s-ABA was more effective at higher concentrations, and the plants drenched with $500 \mathrm{mg} \cdot \mathrm{L}^{-1}$ or sprayed with 500 or $1000 \mathrm{mg} \cdot \mathrm{L}^{-1} \mathrm{~s}-\mathrm{ABA}$ had the longest shelf life extension (Table 1). These plants remained turgid (above a wilt status rating of 3 ) for 5 to $6 \mathrm{~d}$ before visual wilting was observed (Fig. 2). Chrysanthemums that were drenched with 125 and $250 \mathrm{mg} \cdot \mathrm{L}^{-1} \mathrm{~s}-\mathrm{ABA}$ had a shorter shelf life extension, but showed delayed wilting by at least $1 \mathrm{~d}$ compared with control $\left(0 \mathrm{mg} \cdot \mathrm{L}^{-1} \mathrm{~s}-\mathrm{ABA}\right)$ plants (Fig. 2, Table 1).

Spray, drench, and sprench (spray to drench) applications of s-ABA have been shown to delay drought-induced wilting in bedding plants and woody ornamentals (Blanchard et al., 2007; Kim and van Iersel, 2008; van Iersel et al., 2009; Waterland et al., 2010a, 2010 b). Unfortunately, s-ABA applications cause leaf chlorosis, necrosis, and abscission in some species (Blanchard et al., 2007; Kim and van Iersel, 2008; Waterland et al., 2010a, 2010b). Symptoms of phytotoxicity are the most severe following the application of high concentrations of ABA $(500,1000$, or $2000 \mathrm{mg} \cdot \mathrm{L}^{-1} \mathrm{~s}-\mathrm{ABA}$ ) (Kim and van Iersel, 2008; Waterland et al., 2010a, $2010 \mathrm{~b})$. In chrysanthemums, s-ABA applications delayed wilting without causing any apparent damage to leaves or flowers. This product may therefore be useful for extending the postproduction shelf life of chrysanthemums that encounter drought stress during shipping and/or retailing.

Stomatal conductance decreased at $1 \mathrm{~d}$ after s-ABA treatment, indicating that both spray and drench applications effectively induced stomatal closure in treated chrysanthemums. Drought-stressed chrysanthemums treated with s-ABA had a more rapid

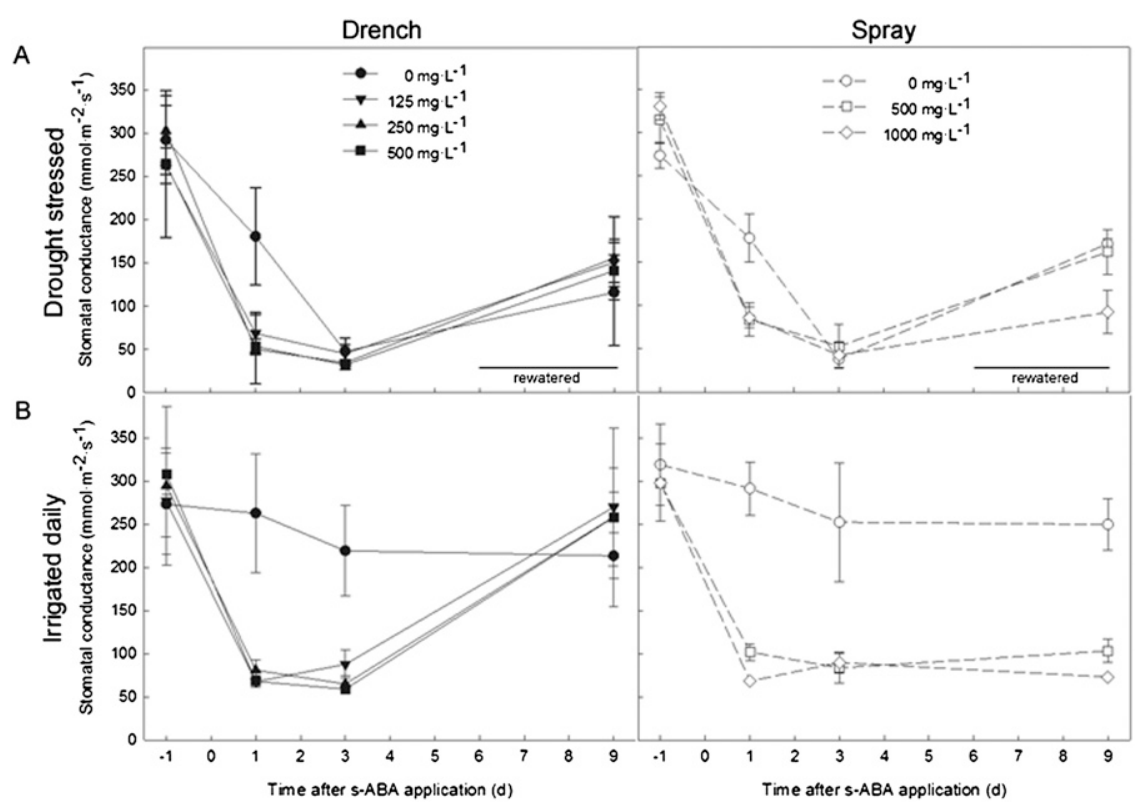

Fig. 3. Stomatal conductance readings of 'Festive Ursula' chrysanthemum treated with s-abscisic acid (s-ABA) as a drench at $0,125,250$, or $500 \mathrm{mg} \cdot \mathrm{L}^{-1}$ or as a spray at 0,500 , or $1000 \mathrm{mg} \cdot \mathrm{L}^{-1}$. Drought-stressed chrysanthemums had water withheld for $6 \mathrm{~d}$ and were then rewatered for $3 \mathrm{~d}$ (A). Stomatal conductance was measured on drought-stressed and subsequently rewatered chrysanthemums (A) and irrigated (B) chrysanthemums after spray or drench applications of s-ABA. Stomatal conductance was measured at Day -1 ( $1 \mathrm{~d}$ before the application of $s-A B A)$ and 1 , 3 , and $9 \mathrm{~d}$ after $\mathrm{s}-\mathrm{ABA}$ treatment. Irrigated chrysanthemums were watered daily with $200 \mathrm{mg} \cdot \mathrm{L}^{-1}$ nitrogen. Values are the mean \pm SD of three replications with three leaves per replication $(\mathrm{n}=3) ; 1 \mathrm{mg} \cdot \mathrm{L}^{-1}=1 \mathrm{ppm}$. 
decrease in $g_{s}$ than non-ABA-treated plants (0 mg. $\left.\mathrm{L}^{-1} \mathrm{~s}-\mathrm{ABA}\right)$, and the largest differences were measured at $1 \mathrm{~d}$ after application (Fig. 3A). By Day 3 , gs was the same in all droughtstressed plants, regardless of s-ABA treatment (Fig. 3A). Both spray and drench applications of s-ABA also resulted in a decrease in $g_{s}$ in all irrigated plants (Fig. 3B). In contrast to the drought-stressed plants, $g_{S}$ in s-ABA-treated plants that were irrigated remained lower than the controls on Day 3.

In salvia (Salvia splendens), drench applications of s-ABA resulted in rapid stomatal closure, and $y_{s}$ decreased within $3 \mathrm{~h}$ of application (Kim and van Iersel, 2008). Stomatal conductance in chrysanthemums may have decreased as rapidly, but our earliest measurement was taken at $\mathrm{l} \mathrm{d}$ after application. Although shelf life extension was clearly rate-dependent, ratedependent differences in $g_{s}$ at $\mathrm{l}$ and $3 \mathrm{~d}$ after treatment were not observed (Table 1, Figs. 2 and 3 ). If chrysanthemum stomata responded within hours of the s-ABA application, these differences may have allowed the plants receiving higher concentrations of s$\mathrm{ABA}$ to close their stomata faster and conserve more soil moisture earlier in the stress response than those treated with lower concentrations. This suggests that the timing of s-ABA application, immediately before any anticipated drought stress, may provide optimal protection.

After $6 \mathrm{~d}$ of drought stress, plants were rewatered to evaluate their recovery. s-ABA-treated plants were visually indistinguishable from the irrigated plants within $3 \mathrm{~d}$ of rewatering (Day 9), while the control plants $\left(0 \mathrm{mg} \cdot \mathrm{L}^{-1}\right.$ s-ABA drench and spray) developed necrosis on the margins of lower leaves (data not shown). Stomatal conductance increased on Day 9 in all rewatered plants, except those that were sprayed with $1000 \mathrm{mg} \cdot \mathrm{L}^{-1} \mathrm{~s}-\mathrm{ABA}$ (Fig. $3 A)$. On Day 9 , the $g_{S}$ of irrigated plants that had been drenched with s-ABA had returned to pre-ABAtreatment rates (Fig. 3B). In contrast, $g_{S}$ was still lower in all irrigated plants that had been sprayed with s-ABA (Fig. 3B). This suggests that spray applications had a longer efficacy than drench applications. In chrysanthemums, the s-ABA may be absorbed and metabolized more quickly from the roots than from the leaves. It is also possible that daily irrigation may have leached some of the s-ABA from the soil before it was taken up by the plant. Previous experiments

with bedding plants indicate that spray applications of s-ABA are more effective at delaying wilting in pansy (Viola $\times$ wittrockiana), while drench

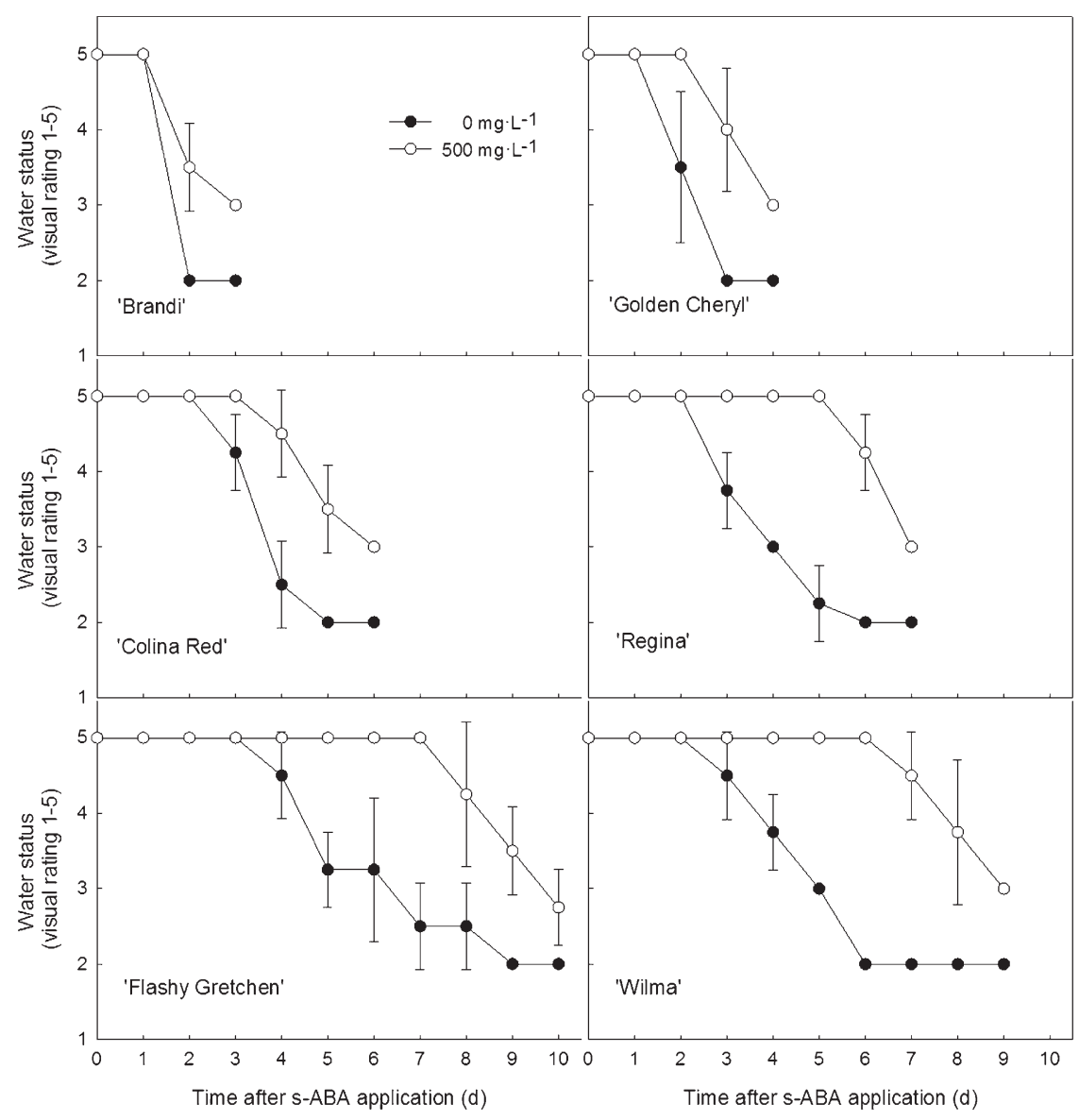

Fig. 4. Wilt status ratings of six cultivars of chrysanthemum after s-abscisic acid (s-ABA) application and withholding water. Chrysanthemums were sprayed with 0 or $500 \mathrm{mg} \cdot \mathrm{L}^{-1} \mathrm{~s}$-ABA. Water was withheld until the $500 \mathrm{mg} \cdot \mathrm{L}^{-1} \mathrm{~s}$-ABA-treated plants were visibly wilted (wilt status rating of 3 or less). Wilt status ratings were from 5 to 1 , where 5 = completely turgid, 4 = soft to touch and starting to wilt, 3 = wilted, 2 = severely wilted, and 1 = wilted to the point that leaves were dry and desiccated. Visual ratings were taken daily with Day 0 just before the s-ABA application ( 1 to $2 \mathrm{~h})$. Values are the means \pm SD of four replications $(\mathrm{n}=4) ; 1 \mathrm{mg} \cdot \mathrm{L}^{-1}=1 \mathrm{ppm}$.

Table 2. Days until the appearance of visual symptoms of wilting and shelf life extension of six cultivars of chrysanthemum treated with s-abscisic acid (s-ABA) at 0 or $500 \mathrm{mg} \cdot \mathrm{L}^{-1}(\mathrm{ppm})$ and drought-stressed.

\begin{tabular}{|c|c|c|c|}
\hline \multirow[b]{2}{*}{ Cultivar } & \multicolumn{2}{|c|}{ Time until visually wilted $(\mathrm{d})^{\mathrm{z}}$} & \multirow{2}{*}{$\begin{array}{c}\text { Shelf life } \\
\text { extension }(d)^{y}\end{array}$} \\
\hline & $0 \mathrm{mg} \cdot \mathrm{L}^{-1}$ & $500 \mathrm{mg} \cdot \mathrm{L}^{-1}$ & \\
\hline Brandi & 1.7 & 2.5 & 0.8 \\
\hline Colina Red & 3.8 & 5.5 & $1.8^{*}$ \\
\hline Flashy Gretchen & 5.5 & 9.3 & $3.8^{*}$ \\
\hline Golden Cheryl & 2.2 & 3.8 & $1.6^{*}$ \\
\hline Regina & 3.8 & 7.0 & $3.3^{*}$ \\
\hline Wilma & 4.8 & 8.5 & $3.8^{*}$ \\
\hline
\end{tabular}

${ }^{2}$ Values are the average number of days from Day 0 that it took each plant to show visible symptoms of wilting, which was a rating of 3 (wilted) on the wilt status rating scale of 5 to 1 , where $5=$ completely turgid, $4=$ soft to the touch and starting to wilt, 3 = wilted, 2 = severely wilted, and $1=$ wilted to the point that leaves were dry and desiccated.

yShelf life extension refers to the number of additional days from the time the control plants wilted until the s-ABAtreated plants wilted. Values are means of four replications $(n=4)$.

* Significant at $P \leq 0.05$ as determined by the least significant difference test. 
applications are more effective in marigold (Tagetes patula) (Waterland et al., 2010a).

Expt. 2. Evaluating cultivar DIFFERENCES. S-ABA delayed visual symptoms of wilting in all six chrysanthemum cultivars treated in Expt. 2. Drought-stressed chrysanthemums treated with $500 \mathrm{mg} \cdot \mathrm{L}^{-1} \mathrm{~s}-\mathrm{ABA}$ remained turgid longer and maintained a higher wilt status rating than the control plants $\left(0 \mathrm{mg} \cdot \mathrm{L}^{-1} \mathrm{~s}-\mathrm{ABA}\right)$ (Fig. $4)$. The delay in wilting and subsequent shelf life extension was cultivar dependent. ABA treatment extended the shelf life of all drought-stressed chrysanthemums except 'Brandi' (Table 2). ABA was most effective in 'Flashy Gretchen' and 'Wilma' (3.8 d shelf life
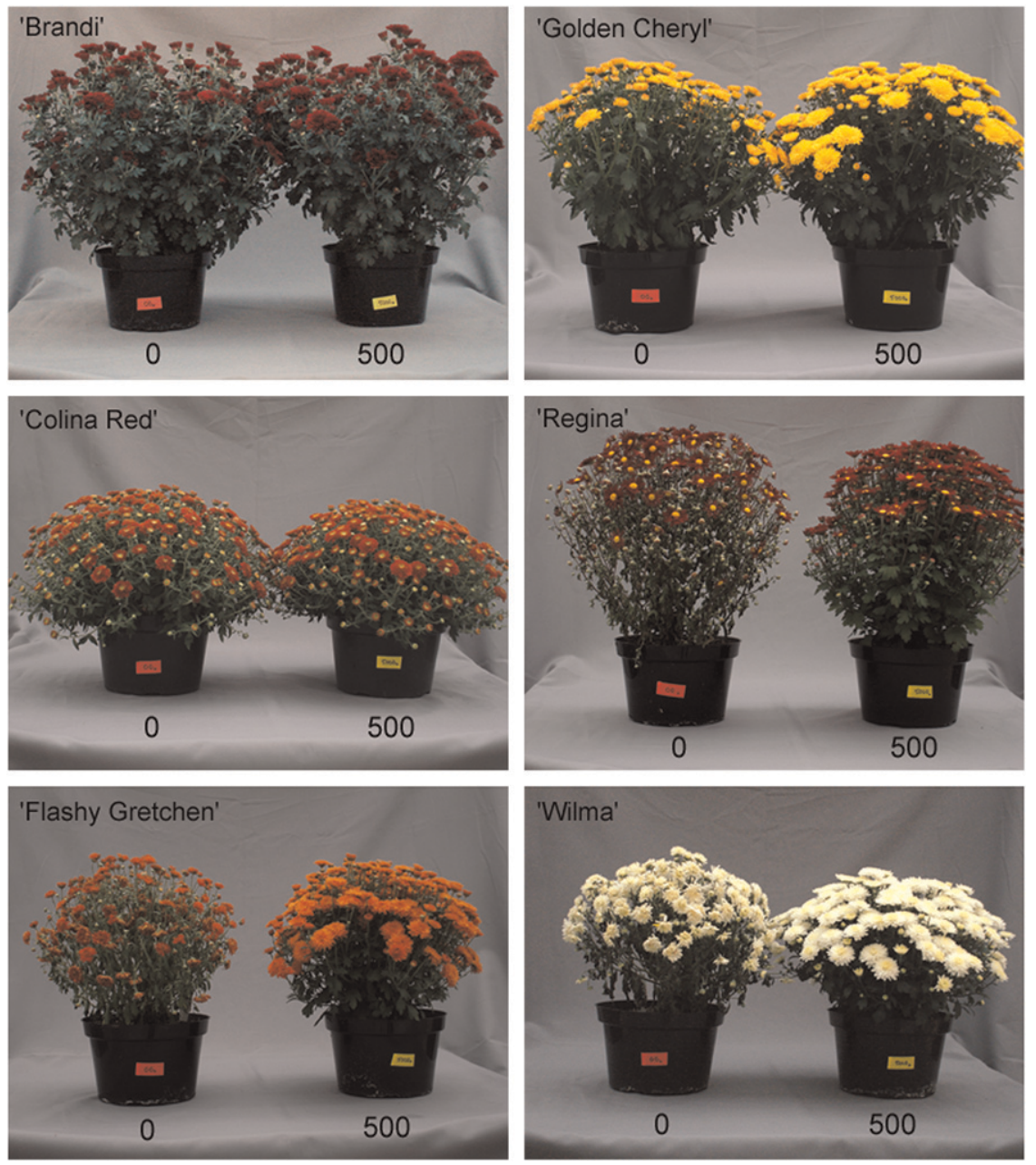

Fig. 5. Visual observation of six cultivars of chrysanthemum after drought stress and subsequent rewatering. Plants were sprayed with 0 or $500 \mathrm{mg} \cdot \mathrm{L}^{-1} \mathrm{~s}$-abscisic acid (s-ABA). Water was withheld until $500 \mathrm{mg} \cdot \mathrm{L}^{-1} \mathrm{~s}$-ABA-treated plants were visibly wilted (wilt status rating of 3 or less), then plants were rewatered for $3 \mathrm{~d}$ to evaluate recovery. Wilt status ratings were from 5 to 1 , where $5=$ completely turgid, $4=$ soft to touch and starting to wilt, $3=$ wilted, $2=$ severely wilted, and $1=$ wilted to the point that leaves were dry and desiccated. Images are representative of all replications $(n=4)$ and were taken at $3 \mathrm{~d}$ after rewatering; $1 \mathrm{mg} \cdot \mathrm{L}^{-1}=1 \mathrm{ppm}$.
(0 mg. $\mathrm{L}^{-1} \mathrm{~s}$-ABA) had leaf chlorosis or necrosis and some of the plants did not regain turgor (Fig. 5). All non-ABA-treated chrysanthemums 'Regina', 'Wilma', and 50\% of 'Flashy Gretchen' did not recover after rewatering and declined to a wilt status rating of 1 . All flowers from these plants were wilted. Rewatered 'Brandi', 'Colina Red', and 'Golden Cheryl' that received no s-ABA regained turgor, but were less marketable than s-ABAtreated plants because they developed basal leaf chlorosis or necrosis on the leaf margins [Fig. 5 (data not shown)].

\section{Conclusion}

Foliar applications of s-ABA delayed symptoms of drought stress in all seven chrysanthemum cultivars evaluated. ABA-treated plants maintained turgor by rapidly closing stomata and reducing transpirational water loss. Although s-ABA effectively delays drought-induced wilting in a variety of floriculture crops, applications can result in leaf abscission and senescence symptoms that reduce the marketability and overall quality of the plants (Blanchard et al., 2007; Kim and van Iersel, 2008; Waterland et al., $2010 \mathrm{a}, 2010 \mathrm{~b})$. In this research, no phytotoxicity was observed and shelf life was extended in all drought-stressed chrysanthemums except the cultivar 'Brandi'. The greatest shelf life extension and delay in wilting was observed with higher concentrations (500 or $1000 \mathrm{mg} \cdot \mathrm{L}^{-1}$ sprays) of s-ABA. s-ABA is a very promising growth regulator that growers can use to protect chrysanthemums from drought stress during shipping and retailing. Decreasing postproduction shrinkage will increase product sell-through and increase profitability for both growers and retailers.

\section{Literature cited}

Armitage, A.M. 1993. Bedding plants: Prolonging shelf performance: Postproduction care and handling. Ball Publ., Batavia, IL.

Barrett, J. and C. Campbell. 2006. SABA: Developing a new tool for the big grower. Big Grower 1(4):26-29.

Blanchard, M.G., L.A. Newton, E.S. Runkle, D. Woolard, and C.A. Campbell. 2007. Exogenous applications of abscisic acid improved the postharvest drought tolerance of several annual bedding plants. Acta Hort. 755:127-132. 
Goreta, S., D.I. Leskovar, and J.L. Jifon. 2007. Gas exchange, water status, and growth of pepper seedlings exposed to transient water deficit stress are differentially altered by antitranspirants. J. Amer. Soc. Hort. Sci. 132:603-610.

Kim, J. and M.W. van Iersel. 2008. ABA drenches induce stomatal closure and prolong shelf life of Salvia splendens. Southern Nursery Assn. Res. Conf. 53:107-111.

Malladi, A. and J.K. Burns. 2007. Communication by plant growth regulators in roots and shoots of horticultural crops. HortScience 42:1113-1117.
Martin, J.D. and C.B. Link. 1973. Reducing water loss of potted chrysanthemums with pre-sale application of antitranspirants. J. Amer. Soc. Hort. Sci. 98:303-306.

Syngenta Flowers Inc. 2010. Garden Mums Stages of Development Chart. 19 Apr. 2010. <http://www.syngentaflowersinc.com/ pdf/cultural/GMStagesOfDevelopment. pdf $>$.

U.S. Department of Agriculture. 2009. Floriculture crops-2008 summary. U.S. Dept. Agr., Natl. Agr. Stat. Serv., Washington, DC. van Iersel, M.W., K. Seader, and S. Dove. 2009. Exogenous abscisic acid application effects on stomatal closure, water use, and shelf life of hydrangea (Hydrangea macrophylla). J. Environ. Hort. 27:234-238.

Waterland, N.L., C.A. Campbell, J.J. Finer, and M.L. Jones. 2010a. Abscisic acid application enhances drought stress tolerance in bedding plants. HortScience 45:409-413.

Waterland, N.L., J.J. Finer, and M.L. Jones. 2010b. Benzyladenine and gibberellic acid application prevents abscisic acid-induced leaf chlorosis in pansy and viola. HortScience 45:925-933. 